\title{
Francis F. Maury, M.D. (1840 to 1879): an often forgotten pioneer in early American surgery.
}

\author{
Guillaume S. Chevrollier, B.S. \\ Thomas Jefferson University \\ Scott W. Cowan, MD \\ Thomas Jefferson University \\ Charles J. Yeo, MD \\ Thomas Jefferson University \\ John C. Kairys, MD \\ Thomas Jefferson University
}

Follow this and additional works at: https://jdc.jefferson.edu/gibbonsocietyprofiles

Part of the History of Science, Technology, and Medicine Commons, and the Surgery Commons Let us know how access to this document benefits you

\section{Recommended Citation}

Chevrollier, B.S., Guillaume S.; Cowan, MD, Scott W.; Yeo, MD, Charles J.; and Kairys, MD, John C., "Francis F. Maury, M.D. (1840 to 1879): an often forgotten pioneer in early American surgery." (2014). Department of Surgery Gibbon Society Historical Profiles. Paper 24.

https://jdc.jefferson.edu/gibbonsocietyprofiles/24

This Article is brought to you for free and open access by the Jefferson Digital Commons. The Jefferson Digital Commons is a service of Thomas Jefferson University's Center for Teaching and Learning (CTL). The Commons is a showcase for Jefferson books and journals, peer-reviewed scholarly publications, unique historical collections from the University archives, and teaching tools. The Jefferson Digital Commons allows researchers and interested readers anywhere in the world to learn about and keep up to date with Jefferson scholarship. This article has been accepted for inclusion in Department of Surgery Gibbon Society Historical Profiles by an authorized administrator of the Jefferson Digital Commons. For more information, please contact: JeffersonDigitalCommons@jefferson.edu. 


\section{Brief Reports}

Brief Reports should be submitted online to www.editorialmanager.com/ amsurg. (See details online under "Instructions for Authors".) They should be no more than 4 double-spaced pages with no Abstract or sub-headings, with a maximum of four (4) references. If figures are included, they should be limited to two (2). The cost of printing color figures is the responsibility of the author.

In general, authors of case reports should use the Brief Report format.

Francis F. Maury, M.D. (1840 to 1879): An Often Forgotten Pioneer in Early American Surgery

Francis F. Maury (Fig. 1) was born on August 9, 1840, in Danville, Kentucky, where he was raised on a farm by his mother and father. His father was an Episcopal clergyman of Huguenot descent, whose forefathers had fled from France to escape religious persecution. After receiving a Bachelor of Arts degree from Center College in the summer of 1860 , he entered medical school at the University of Virginia. After one full term, he matriculated to Philadelphia's Jefferson Medical College and completed his medical education as a private student under the direction of Dr. Samuel D. Gross. ${ }^{1,2}$ He obtained his Doctorate of Medicine in March of 1862 at the age of only 21 years. Such were his talents as a medical student that he was appointed resident physician at the Philadelphia Hospital one month before his graduation. Although he spent only one year there, he developed a reputation as a tireless, devoted, and charming surgeon. In April 1863, Maury was assigned to duty at the South Street General Hospital to serve as acting assistant surgeon in the U.S. Army for two years. In October 1863, he was appointed assistant professor to Dr. Gross and six months later became chief of Dr. Gross' surgical clinic at Jefferson Medical College. In November 1865, at the age of only 25 years, he returned to the Philadelphia Hospital, where he was appointed one of the chief surgeons on the retirement of Dr. Gross from that institution. In April of 1866, Maury founded the Summer Course on Venereal and Cutaneous Diseases in the Jefferson Medical College, where he taught until his death. ${ }^{1}$ Although Maury did not consider himself a dermatologist, his expertise in this emerging field was widely recognized. ${ }^{1,2}$

In 1866, Maury married Katherine Ingersol. He would go on to serve as a member of myriad medical associations throughout his career, including the College

Address correspondence and reprint requests to Scott W. Cowan, M.D., Associate Professor of Surgery, 1025 Walnut Street, Suite 607, Philadelphia, PA 19107. E-mail: scott.cowan@jefferson.edu. of Physicians of Philadelphia, the Pathological Society of Philadelphia, the American Dermatological Association, the Academy of Natural Sciences, and the Philadelphia County Medical Society. Together with Dr. Louis A. Duhring, Maury edited the Photographic Review of Medicine and Surgery, in which he wrote four articles. ${ }^{1}$

Maury was considered one of the brightest and boldest surgeons of his time, most widely known for performing the first gastrostomy in America on June 25, 1869. In his report published in April 1870, Maury details the procedure performed on a 26-year-old man whose syphilitic esophageal stricture had failed to respond to mechanical dilation. His patient was so weak and emaciated from starvation that he had become bedbound, resorting to brandy, beef extract, and milkpunch enema for survival. In the procedure, performed under chloroform anesthesia, Maury reached the stomach by way of a curvilinear incision starting at the sternal border of the seventh intercostal space and traveling down and laterally approximately four inches. A 1-inch incision was made into the stomach proper and the newly created free edges of the stomach were attached to the edges of the opening in the abdominal wall. A tube was inserted into the stomach and tied into position with tape wrapped around the body and the wound was closed. On closure of the wound, beef extract, brandy, and water were successfully transferred to the stomach and retained. Unfortunately, as had been the case with all previously described gastrostomies, long-term postoperative survival was

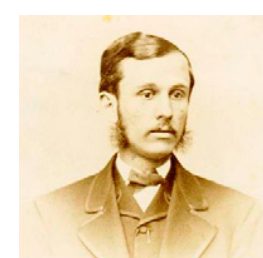

FIg. 1. Francis F. Maury. Courtesy of Thomas Jefferson University Archives \& Special Collections. 
not achieved and the patient died only 14 hours later. ${ }^{3}$ Although the surgery was technically successful, Maury explained "I now regret, however that I did not propose the operation as soon as the patient became unable to take solid food. So great is my conviction that the procedure is justifiable, and to be regarded as one of the established operations of surgery, that I would have no hesitation in resorting to it." At a time when gastrostomies had yet to attain any degree of sustained survival, Maury was instrumental in the incorporation and advancement of gastrostomy as part of American surgery. ${ }^{3}$

Less renowned, but perhaps even more remarkable than his gastrostomy, were Maury's two thyroidectomies performed in 1871. Among the first in the United States, they were performed at a time when the mortality rate from this operation was estimated to be more than 40 per cent, a percentage so high that the French Academy of Medicine condemned its practice in 1850. Accordingly, this operation was frowned on by many of the day's most respected surgeons, including Maury's beloved mentor, Dr. Gross, who had written just five years earlier "If a surgeon should be so adventurous or foolhardy as to undertake thyroidectomy, every step he takes will be environed with difficulty, every stroke of his knife will be followed by a torrent of blood, and lucky will it be for him if his victim lives long enough to enable him to finish his horrid butchery. Should the patient survive the immediate effects of the operation, if thus it may be called, death will be almost certain to overtake him... No honest and sensible surgeon, it seems to me, would ever engage in it." 4 Although Maury's second patient died of pneumonia 21 days after surgery, his first recovered to live "in the enjoyment of perfect health." It was through such daring work by a few courageous surgeons and technological advances by the likes of Theodor Billroth and Theodor Kocher that thyroidectomies became safer and gained gradual acceptance in surgical practice..$^{5}$ Maury's other notable published operations included a partial brachial plexus excision for a painful neuroma of the skin, removal of an enormous keloid encircling the neck, surgical correction for bladder exstrophy, bladder lithotomy and lithotrity, and hip amputation. ${ }^{1}$

Judging from the wide variety of operations he performed, Dr. Francis F. Maury was a true general surgeon in every sense, known for his dexterity and sound judgment in the operating room, his tireless devotion to patients, and his captivating style of teaching. Coming from very modest means, his incredibly successful career and rapid rise to prominence were in every way a product of his own labor. His professional prowess was best described by Dr. Samuel W. Gross, the son of Samuel D. Gross, who assisted in many of Maury's

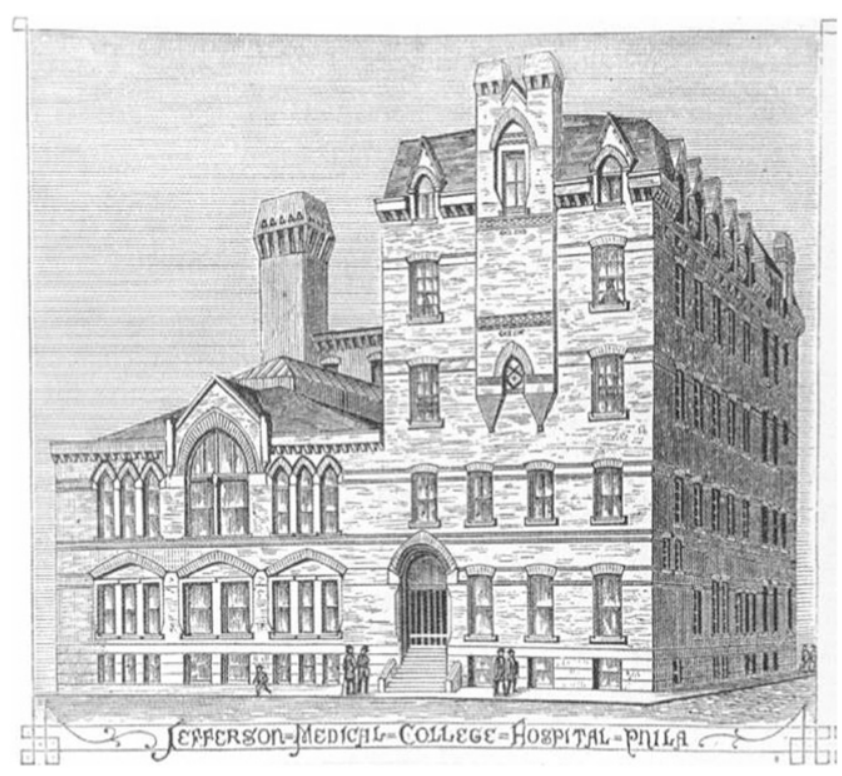

FIG. 2. The first detached Jefferson Medical College Hospital officially opened on September 17, 1877, 18 days after the first operation was performed there by Dr. Francis Maury. ${ }^{2}$

surgeries: “. . he soon became a great favorite, and his personal magnetism was such that he was looked up to by his superiors, equals, and inferiors... The residents swore by him, the patients and nurses worshipped him." 1

At Jefferson Medical College, Maury played a critical role in establishing the first detached Jefferson Medical College Hospital (Fig. 2) when he secured the incredible sum of $\$ 100,000$ from the Pennsylvania State Legislature; the final cost of the project came to $\$ 186,000$. As fate would have it, Maury performed the first operation in the new hospital on August 30, 1877, where he amputated the left middle finger of Malcolm Meyer, the son of the Speaker of the Pennsylvania House of Representatives. ${ }^{2}$ Unfortunately, after the death of his wife in March of 1879, Maury became ill and died nine weeks later of tuberculosis at the age of 39 years. Although his life and career were cut short, Francis F. Maury's daring and groundbreaking work left an early mark on a variety of surgical approaches in a time when the concept of specialty medicine was just beginning to emerge.

Guillaume S. Chevrollier, B.S. Scott W. Cowan, M.D. Charles J. Yeo, M.D. John C. Kairys, M.D.

Department of Surgery Thomas Jefferson University Jefferson Medical College Philadelphia, Pennsylvania 


\section{REFERENCES}

1. Gross SW. Francis Fontaine Maury: 1840-1879. In: Croskey JW, ed. History of Blockley: A History of the Philadelphia General Hospital from its Inception, 1731-1928. Philadelphia, PA: F.A. Davis Company; 1929:418-21.

2. Part I: Jefferson Medical College (1824-1895)Chapter 2: Growth and Consolidation (pages 46-104) and Part III: Clinical Departments and Divisions-Chapter 27: Department of Dermatology (pages 457-464). Wagner FB Jr, ed. Thomas Jefferson University-Tradition and Heritage;
1989. Papers 27 and 49. Available at: http://jdc.jefferson.edu/ wagner2/. Accessed March 24, 2013.

3. Maury FF. Case of stricture of the oesophagus in which gastrostomy was performed. AJMS 1870;CXVIII:365-71.

4. Ellis H. Surgery. In: Ellis H, ed. A History of Surgery. London, UK: Geenwich Medical Media Limited; 2001:200-3.

5. Maury FF. Extirpation of the thyroid gland for cystic enlargement. In: Maury FF, Duhring LA, eds. Photographic Review of Medicine and Surgery. Vol. II. Philadelphia, PA: J.B. Lippincott \& Co; 1872:17-8. 